\title{
Alterations in antioxidant defense system in hepatic and renal tissues of rats following aspartame intake
}

\author{
Saeed A. Alwaleedi* \\ Department of Biology, Faculty of Science, Taif University (TU), Taif, Saudi Arabia.
}

\begin{tabular}{|c|c|}
\hline ARTICLE INFO & ABSTRACT \\
\hline $\begin{array}{l}\text { Article history: } \\
\text { Received on: } 02 / 02 / 2016 \\
\text { Revised on: } 14 / 03 / 2016 \\
\text { Accepted on: } 09 / 04 / 2016 \\
\text { Available online: } 21 / 04 / 2016\end{array}$ & $\begin{array}{l}\text { Aspartame is one of the most common artificial sweeteners in use today worldwide. Aspartame has been } \\
\text { implicated in many health problems. The study aimed to investigate whether aspartame consumption induces } \\
\text { oxidative stress and whether it can threaten the antioxidant defense system in hepatic and renal tissues. The } \\
\text { experiment was performed on adult male albino rats. They were distributed into } 4 \text { groups, group I represented the } \\
\text { control animals and received orally water. The rest were given aspartame in a dose } 50 \mathrm{mg} / \mathrm{kg} \text { for } 15,30 \text { and } 60 \\
\text { days respectively. Blood was collected and centrifuged to obtain serum for the determination of serum enzymes. }\end{array}$ \\
\hline $\begin{array}{l}\text { Key words: } \\
\text { aspartame, oxidative stress, } \\
\text { antioxidant, free radicals, } \\
\text { liver, kidney }\end{array}$ & $\begin{array}{l}\text { The tissue samples were homogenized, centrifuged and the clear supernatant was collected for further } \\
\text { biochemical analysis. The results showed a significant increase in LPO level in liver and kidney. A remarkable } \\
\text { reduction in GSH content was also observed in both hepatic and renal tissues. The activities of antioxidant } \\
\text { enzymes SOD, CAT, GPx and GR were significantly reduced in both liver and kidney. In addition, the results } \\
\text { also indicated a significant increase in activities of serum marker enzymes ALT, AST, ALP and GGT. The data } \\
\text { provided in this study clearly point out that aspartame consumption at a dose of } 50 \mathrm{mg} / \mathrm{kg} \text { induces oxidative } \\
\text { stress in hepatic and renal tissues by generation of free radicals. }\end{array}$ \\
\hline
\end{tabular}

\section{INTRODUCTION}

Aspartame (L-aspartyl L-phenylalanine methylester) is a dipeptide artificial sweetener which is widely used as nonnutritive sweetener in foods and drinks in over 90 countries worldwide [1]. It is used in a variety of beverages, foods, desserts, sweets, breakfast cereals, chewing gum and weight control products. It is also used as a tabletop sweetener and in pharmaceuticals [2]. Following aspartame ingestion, none of it actually enters the blood intact. However, it is rapidly absorbed from the intestinal lumen and metabolized to aspartic acid, phenylalanine and methanol [3]. Upon aspartame consumption, the concentrations of its metabolites increased in the blood [4]. Concern relating to the possible adverse effects has been raised due to aspartame metabolic components which are formed during its breakdown. Any health effects from aspartame consumption are caused by these compounds which are absorbed into the blood [5]. Aspartic acid and phenylalanine are both amino acids which are found naturally in proteins and under normal

\footnotetext{
* Corresponding Author

Saeed A. Alwaleedi, Department of Biology, Faculty of Science, Taif University (TU), Taif, Saudi Arabia.Email: swaleedi@hotmail.com
}

conditions they are important for health [6]. However, due to easily crossing the blood-brain barrier, they are neurotoxic when unaccompanied by the other amino acids in proteins [7]. Certain brain amino acid levels have been shown to be increased following aspartame intake and therefore may cause brain damage [8,9]. It has been observed that aspartame intake was associated with neurological and behavioral disturbances [10]. Among these metabolites, methanol is a toxicant which may cause systemic toxicity [11]. Relatively consumption of small amount of aspartame can markedly elevate plasma methanol concentration [12]. Methanol is being increasingly recognized as a substance that damages the liver cells where it is oxidized to formaldehyde and later to formate [5]. These processes are accompanied by elevation of NADH level and the formation of superoxide anion which may be involved in lipid peroxidation $[13,14]$. Also, methanol intoxication is associated with mitochondrial damage and increased microsomal proliferation resulting in increased production of oxygen radicals [15]. These factors together with the excess of formaldehyde, formed during acute methanol intoxication cause significant increase in lipid peroxidation [14]. The metabolism of xenobiotics to a large extent takes place in the liver. The byproducts of such metabolism sometimes are more toxic than the initial substance. 
This could lead to hepatic damage and the emergence of hepatic disorders [16]. These byproducts include oxygen containing molecules that damage vital cell components through oxidation [17]. They can produce deleterious effects by reacting with complex cellular molecules such as lipids, proteins and DNA. Oxidative stress defined as a disturbance in the balance between the production of reactive oxygen species (ROS) and the ability of the body to counteract or detoxify their harmful effects through neutralization by antioxidants [18]. Excessive formation and inadequate removal of free radicals lead to destructive and irreversible cell damage [19].

Therefore, this study aimed to investigate whether the oral administration of aspartame at a dose of $50 \mathrm{mg} / \mathrm{kg}$ of the body weight induces oxidative stress and whether it has harmful effects on the antioxidant defense system in hepatic and renal tissues of male albino rats. In addition, the study investigated the effect of aspartame consumption on the activities of hepatic marker enzymes.

\section{MATERIALS AND METHODS}

\subsection{Animals and experimental design}

The experiment was performed on inbred, healthy adult male albino rats aged 12 weeks and weighing 160-180 g. The experimental animals were kept under fixed appropriate conditions of housing and handling throughout the experimental period. They were kept in standard neat metallic and well-ventillated cages. They maintained on healthy laboratory conditions at temperature of $18-24^{\circ} \mathrm{C}$ and 12 hours light and darkness with an appropriate humidity.

The rats were adapted to the new environment for 14 days prior to study start. Animals received humane care in accordance with the guidelines of the national institute of health, USA, for ethical treatment of laboratory animals. All rats had free access to drinking water and food, ad libitum, during the experimental period. They were fed with standard pellet diet obtained from LabDiet, Missouri, USA. The rats were randomly distributed into 4 groups, each comprised of 5 animals. Group I represented the healthy control animals and received orally water at each time segment of the experiment. Groups II, III, and IV were given aspartame dissolved in water in a dose $50 \mathrm{mg} / \mathrm{kg}$ for 15,30 and 60 days respectively.

\subsection{Sample collection and preparation}

At the end of the experimental period, the animals were euthanized and decapitated after being fasted. Blood was collected and centrifuged at $2500 \mathrm{rpm}$ for $20 \mathrm{~min}$ using centrifuge 5418R (Eppendorf, Ontario, Canada); the clear serum obtained was used for the determination of serum enzymes.

The liver and kidney of each animal were excised immediatley, washed in ice cold saline and blotted in a filter paper to dryness. Quickly after weighed, the tissue samples were homogenized by using Teflon glass homogenizer. The homogenate of these tissues were prepared in ice cold phosphate buffer (50
$\mathrm{mM}, \mathrm{pH} 7.4,0.1 \%$ triton and $0.5 \mathrm{mM}$ EDTA) and then centrifuged at $3000 \mathrm{~g}, 4^{\circ} \mathrm{C}$ for $15 \mathrm{~min}$ using cooling centrifuge (type $3 \mathrm{~K}-30$, Sigma, Germany) to remove cell debris, the clear supernatant was collected and used for further biochemical analysis using the Roche Hitachi/704 chemistry auto-analyzer (Roche Diagnostics Corporation, Indianapolis, USA).

\subsection{Quantification of LPO and GSH levels}

The process of lipid peroxidation (LPO) measurement was carried out using lipid peroxidation (MDA) assay kit (Sigmaaldrich Ltd., UK) in accordance to the manufacturer's instructions. In this assay, lipid peroxidation is determined by the reaction of malondialdehyde (MDA) with thiobarbituric acid (TBA) to form a colorimetric product, proportional to the MDA present. To form the MDA-TBA adduct, the TBA solution $(600 \mathrm{~mL})$ was added into each sample and incubated at $95^{\circ} \mathrm{C}$ for $60 \mathrm{~min}$, prior to cool to room temperature in an ice bath for $10 \mathrm{~min}$. Each reaction mixture (200 mL) was transferred into a 96-well plate for analysis. The absorbance was measured at $532 \mathrm{~nm}$. Measurement of glutathione (GSH) level was carried out using GSH assay kit (Sigma). The biological sample is first deproteinized with the $5 \%$ sulfosalicylic acid solution, centrifuged to remove the precipitated protein, and then assayed for glutathione. The measurement of GSH uses a kinetic assay in which catalytic amounts of GSH cause a continuous reduction of 5-dithiobis nitrobenzoic acid (DTNB) to 5-thio nitrobenzoic acid (TNB) and the oxidised glutathion formed is recycled by glutathione reductase and nicotinamide adenine dinucleotide phosphate (NADPH). The reaction rate is proportional to the concentration of glutathione. The yellow product, TNB is measured spectrophotometrically at $412 \mathrm{~nm}$.

\subsection{Determination of enzyme activities}

The activity of Superoxide dismutase (SOD) was determined using SOD assay kit (Sigma) according to the manufacturer's instructions. In this kit, water soluble tetrazolium allows very convenient SOD assaying by utilizing Dojindo's highly WST salt that produces a water soluble formazan dye upon reduction with a superoxide anion. The rate of the reduction with oxygen is linearly related to the xanthine oxidase (XO) activity, and is inhibited by SOD.

Therefore, the activity of SOD can be determined by a colorimetric method. Since the absorbance at $440 \mathrm{~nm}$ is proportional to the amount of superoxide anion, the SOD activity as an inhibition activity can be quantified by measuring the decrease in the color development at $440 \mathrm{~nm}$. In order to determine the catalase activity, CAT assay kit (Sigma) was used in accordance to the manufacturer's instructions. Catalase is able to decompose hydrogen peroxide by the catalatic pathway, where two molecules of hydrogen peroxide are converted to water and oxygen (catalatic activity).

This assay method is based on the measurement of the hydrogen peroxide substrate remaining after the action of catalase. First, the catalase converts hydrogen peroxide to water and oxygen and then this enzymatic reaction is stopped with sodium azide. An 
aliquot of the reaction mix is then assayed for the amount of hydrogen peroxide remaining by a colorimetric method which uses a substituted phenol, which couples oxidatively to 4aminoantipyrine in the presence of hydrogen peroxide and horseradish peroxidase (HRP) to give a red quinoneimine dye that absorbs at $520 \mathrm{~nm}$. Glutathione peroxidase (GPx) activity was determined using GPx cellular activity assay kit (Sigma) according to the manufacturer's instructions. This kit uses an indirect determination method. It is based on the oxidation of reduced glutathione (GSH) to oxidized glutathione (GSSG) catalyzed by GPx, which is then coupled to the recycling of GSSG back to GSH utilizing glutathione reductase and NADPH. The decrease in NADPH absorbance, measured at $340 \mathrm{~nm}$ during its oxidation, is an indicative of GPx activity.

The reaction was performed at $25^{\circ} \mathrm{C}, \mathrm{pH} 8.0$, and was started by adding organic peroxide, tert-butyl hydroperoxide. This substrate is suitable for the assay since its spontaneous reaction with GSH is low and it is not metabolized by catalase. The reaction with tert-butyl hydroperoxide measures the amount of glutathione peroxidase activity present. The activity of Glutathione reductase (GR) was measured using GR assay kit (Sigma). This assay is based on the reduction of GSSG by NADPH in the presence of glutathione reductase. In addition, 5-dithiobis nitrobenzoic acid reacts with GSH formed. The first reaction is measured by the decrease in absorbance at $340 \mathrm{~nm}$ for NADPH and the second reaction is measured by the increase in absorbance at $412 \mathrm{~nm}$ for 5-thio nitrobenzoic acid.

The glutathione-S-transferase (GST) activity was measured by GST assay kit (Sigma) which utilizes chloro dinitrobenzene (CDNB), which is suitable for the broadest range of GST isozymes. Upon conjugation of the thiol group of glutathione to the CDNB substrate, there is an increase in the absorbance at $340 \mathrm{~nm}$.

For determination of alanine aminotransferase (ALT) activity, the serum sample was added to the buffered solution containing DL-alanine and 2-ketoglutarate $(\mathrm{pH} 7.4)$ and incubated for $30 \mathrm{~min}$ at $37^{\circ} \mathrm{C}$. After incubation, $1.0 \mathrm{mM}$, DNPH was added, followed by the addition of $\mathrm{NaOH}(0.4 \mathrm{M})$. The absorbance was read at $500 \mathrm{~nm}$ and the ALT activity deduced. For determination of aspartate aminotransferase (AST) activity in serum, L-aspartic acid was used in place of the DL-alanine and the incubation time was $1 \mathrm{hr}$. For determination of $\gamma$-glutamyl transferase (GGT) activity, the serum sample was added to a substrate solution containing glycylglycine, magnesium chloride and $\gamma$-glutamylpnitroanilide in tris $(0.05 \mathrm{M}), \mathrm{pH} 8.2$. The mixture was incubated at $37^{\circ} \mathrm{C}$ for $1 \mathrm{~min}$ and the absorbance read at $405 \mathrm{~nm}$ at $1 \mathrm{~min}$ interval for $5 \mathrm{~min}$. Alkaline phosphatase (ALP), in alkaline medium, hydrolyzes a colorless substrate of disodium phenyl phosphate giving rise to phenol and phosphate. 4-aminoantipyrine and sodium arsenate are used to stop the enzymatic reaction. The liberated phenol was measured colorimetrically by adding potassium ferricyanide as a color developing reagent.

\subsection{Statistical analysis}

Data obtained from this investigation were statistically evaluated using the SPSS software version 20 (SPSS Institute Inc., USA). Results were expressed as means \pm standard error of mean (SE) and analysed using analysis of variance (ANOVA), while comparison were made using Student's $t$-test at $\mathrm{P}<0.05$ level of significance.

\section{RESULTS}

The current study investigated the influence of oral administration of aspartame (50 mg/kg body weight) on liver and kidney of adult male rats at different three period of time. The results showed a significant $(\mathrm{P}<0.05)$ elevation in LPO level in the liver cells of aspartame treated animals after 30 and 60 days of treatment comparing with the control ones (table 1).

The data also revealed that LPO level increased significantly after 30 and 60 days when compared to 15 days of aspartame exposure. Regarding the renal tissue, the data represented a significant increase in LPO level after 30 and 60 days of oral administration of aspartame relative to the healthy control animals. In addition, LPO level was significantly elevated after 30 and 60 days of treatment comparing to 15 days.

The results also represented that GSH content was significantly decreased in the liver tissue of the experimental animals after 30 and 60 days of aspartame exposure relative to the control animals (table 1). In addition, a remarkable $(\mathrm{P}<0.05)$ reduction in GSH content was also observed in the renal tissue of the aspartame treated animals when compared with the control.

The GPx and GR activities were significantly $(\mathrm{P}<0.05)$ reduced in both liver and renal tissues in the experimental animals after 30 and 60 days of oral administration of aspartame in comparison with the control animals (fig 1 and 2). No significant changes were observed after 15 days of exposure. The data in fig 1 showed a remarkable reduction in the activity of SOD in the liver tissue after 15, 30 and 60 days of treatment. The results also showed a significant $(\mathrm{P}<0.05)$ decrease in SOD activity in kidney tissue in aspartame-treated animals compared with the control rats (fig 2). The activity of CAT was significantly $(\mathrm{P}<0.05)$ decreased in liver and renal tissues of the experimental animals after 30 and 60 days of aspartame administration when compared with the healthy control animals. No significant change was observed in CAT activity after 15 days.

The aspartame treated animals showed a marked increase in the GST activity in the liver tissue after the different three periods of time comparing with the control ones. However, there was a non significant impact of aspartame on the activity of GST in rat renal tissue after 15, 30 and 60 days of aspartame treatment. In addition, the results of this investigation also indicated a significant increase in activities of hepatic marker enzymes in serum including ALT, AST, ALP and GGT (fig 3). 
Table 1: Effect of aspartame on LPO level and GSH concentration in liver and kidney of rats.

\begin{tabular}{|c|c|c|c|c|}
\hline \multirow[t]{2}{*}{ Parameter } & \multirow[t]{2}{*}{ Control } & \multicolumn{3}{|c|}{ Time period } \\
\hline & & 15 days & 30 days & 60 days \\
\hline \multicolumn{5}{|l|}{ Liver tissue: } \\
\hline$\overline{\mathrm{MDA}}(\mathrm{nmol} / \mathrm{g}$ tissue) & $60.25 \pm 0.73$ & $65.91 \pm 0.53$ & $83.54 \pm 0.34 *$ & $90.13 \pm 0.46^{*}$ \\
\hline GSH (mg/g tissue) & $103.5 \pm 0.85$ & $92.72 \pm 0.64 *$ & $74.11 \pm 0.73 *$ & $61.37 \pm 0.51 *$ \\
\hline \multicolumn{5}{|l|}{ Kidney tissue: } \\
\hline$\overline{\mathrm{MDA}(\mathrm{nmol} / \mathrm{g}}$ tissue) & $53.03 \pm 0.44$ & $64.61 \pm 0.72$ & $68.72 \pm 0.56^{*}$ & $81.34 \pm 0.88^{*}$ \\
\hline GSH (mg/g tissue) & $91.87 \pm 0.67$ & $83.16 \pm 0.38$ & $76.31 \pm 0.92 *$ & $70.27 \pm 0.47 *$ \\
\hline
\end{tabular}

Aspartame concentration used $(50 \mathrm{mg} / \mathrm{kg}$ bd wt) at different three time periods, LPO, lipid peroxidation;

MDA, malondialdehyde; GSH, reduced glutathione. Values are represented as mean $\pm \mathrm{SE}, \mathrm{n}=5$, * $\mathrm{P}<0.05$ compared with control

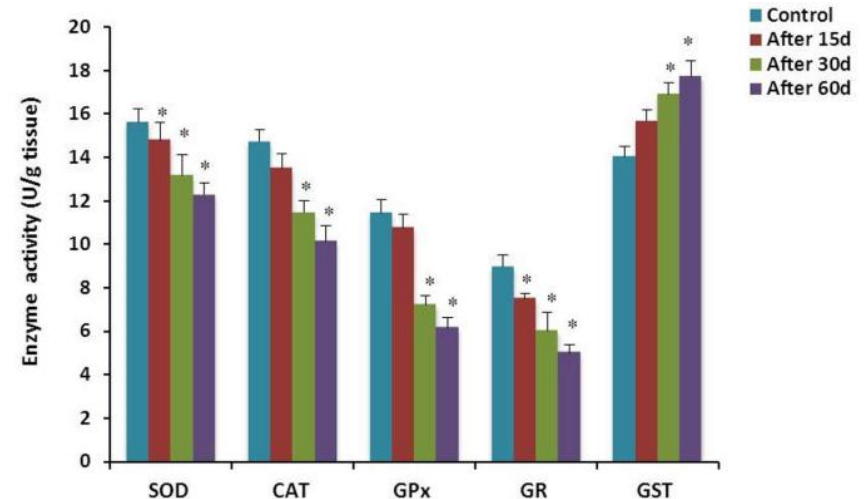

Fig. 1: Alteration in antioxidant enzymes in the liver of male rats at different time period after oral administration of aspartame. Blue colour denotes control group, while brown, green and violet indicates changes in enzyme activities (U/g tissue) after 15,30 and 60 days of aspartame treatment $(50 \mathrm{mg} / \mathrm{kg})$ respectively. SOD, superoxide dismutase; CAT, catalase; GPx, glutathione peroxidase; GR, glutathione reductase; GST, glutathione-S-transferase. Data are expressed as mean $\pm \mathrm{SE}, \mathrm{n}=5, * \mathrm{P}<0.05$ compared with control.

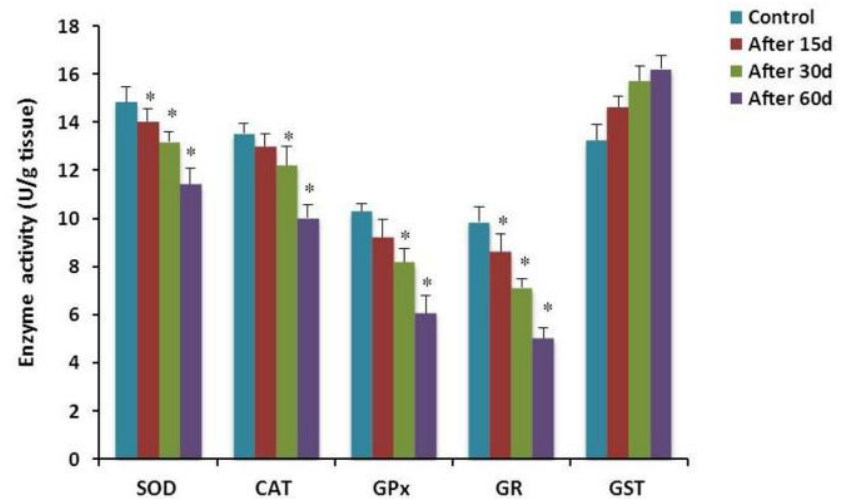

Fig. 2: Effect of aspartame on antioxidant enzymes in the kidney of male rats at different time period. Blue colour denotes control group, while brown, green and violet indicates alteration in enzyme activities (U/g tissue) after 15 , 30 and 60 days of oral administration of aspartame $(50 \mathrm{mg} / \mathrm{kg})$ respectively. SOD, superoxide dismutase; CAT, catalase; GPx, glutathione peroxidase; GR, glutathione reductase; GST, glutathione-S-transferase. Data are expressed as mean $\pm \mathrm{SE}, \mathrm{n}=5, * \mathrm{P}<0.05$ compared with control.

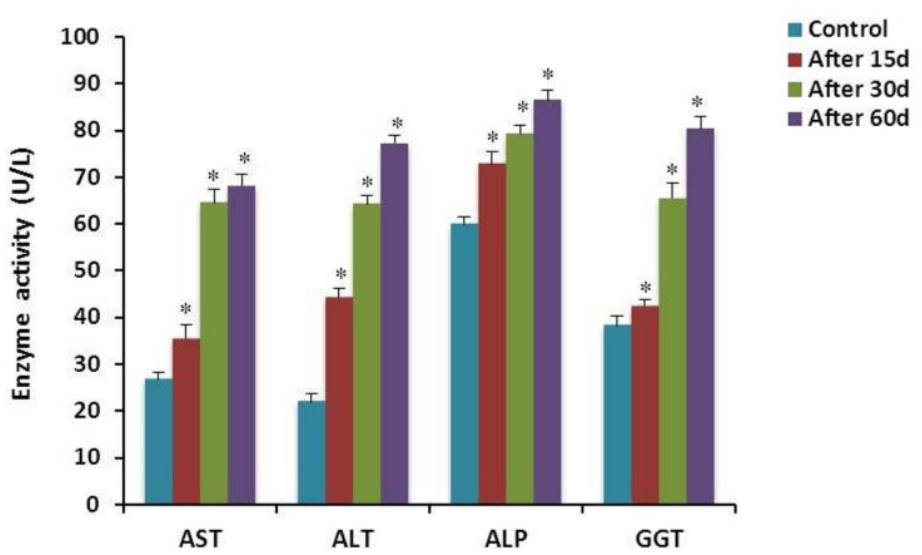

Fig. 3: Effect of aspartame on marker enzymes in blood serum of male rats at different three time period. Blue colour denotes control group, while brown, green and violet indicates alteration in enzymatic activities (U/L) after 15, 30 and 60 days of oral administration of aspartame (50 mg/kg) respectively. AST, aspartate aminotransferase; ALT, alanine aminotransferase; ALP, alkaine phosphatase; GGT, gamma glutamyl transferase. Values are expressed as mean \pm SE, $\mathrm{n}=5, * \mathrm{P}<0.05$ compared with control.

\section{DISCUSSION}

Aspartame is one of the most common artificial sweeteners in use today. It has a wide acceptance as an additive in soft drink, liquid beverages and other low-calorie or free-sugar foods throughout the world. However, there are different health symptoms associated with aspartame consumption such as headache, dizziness, ear buzzing, nausea, fatigue, change in vision, depression, high serum AST and pancreatitis [6]. Aspartame has been suggested to be metabolized in the digestive tract into $50 \%$ phenylalanine, $40 \%$ aspartic acid and $10 \%$ methanol [20,21]. Some of phenylalanine, produced in the gastrointestinal tract following aspartame intake, is eliminated in the form of carbon dioxide. However, most of it is integrated into the amino acids pool and participates in protein biosynthesis [21,22]. Aspartic acid is predominately removed through the respiratory system in the form of carbon dioxide. It has been reported that the plasma concentration of aspartic acid does not increase markedly following aspartame ingestion at a dose of $34 \mathrm{mg} / \mathrm{kg}$ [23]. Methanol is mostly oxidized to formaldehyde and later to formate. 
These transformations are accompanied by production of hydrogen peroxide and superoxide anion [14]. The current work showed a significant increase in the level of LPO in liver and renal tissues after 30 and 60 days of oral administration of aspartame. LPO is an auto catalytic process leading to oxidative degradation of lipids causing demolition of cell membranes and subsequently cell damage [24]. It is mainly generated by the effect of various reactive oxygen species (ROS) such as hydrogen peroxide, superoxides and hydroxyl radical [25]. LPO is a chain reaction initiated by the hydrogen abstraction from the side chain of polyunsaturated fatty acids resulting in cell membranes deterioration [26]. Decomposition of latest compounds lead to production of several products particularly malondialdehyde (MDA) [27]. This tending to diminish the fluidity of cell membrane which plays a vital role in cell functioning. The elevated level of MDA observed in the current work, which is an indicator of LPO, denotes cell membrane damage in liver and kidney of aspartame treated animals. It has been reported an increase in MDA level in rat lymphoid organs after methanol administration [14]. A significant elevation in MDA level has been observed in renal tissue when rats treated with formaldehyde [28].

Glutathione is a non-enzymatic cellular antioxidant which plays a crucial role in scavenging damaging free radicals. GSH can function as a co-substrate for peroxide detoxification by glutathione peroxidases [29]. GSH also catalyses the reduction of hydrogen peroxide to water [30]. GSH non-enzymatically reacts with superoxides, hydroxyl radicals and singlet oxygen [31,32]. Therefore, reactive oxygen species are quenched by interaction with GSH before they can initiate their chain reaction damaging effects [33]. Deplition of cellular glutathione content may be one of the reasons for the increase in cell vulnerability to oxidative stress $[34,35]$. The decline in GSH level in this investigation could be caused by methanol intoxication following aspartame administration, because glutathione participates in the regulation of methanol metabolism [36]. In addition, the reduction in GSH activity might be due to its rapid reaction with formaldehyde, which formed during methanol metabolism, to produce LPO products and nucleophilic adducts [37]. Hence, the decrease in GSH content may be owing to the excessive exploitation of this antioxidant to scavenge the free radicals produced during aspartame metabolism.

The plasma concentrations of methanol, a metabolite of aspartame, were markedly increased following administration of a small amount of aspartame [12]. The antioxidant defense system involving cellular GSH content and the activities of associated enzymes were reduced in liver tissue during methanol intoxication [38]. In the present investigation, the activities of antioxidant enzymes GPx, GR, SOD and CAT were decreased significantly in aspartame-treated animals when compared to the control ones. Reduced activities of these enzymes as well as GSH level might be owing to the damaging impact of free radicals formed after methanol metaboilism from aspartame. In addition, this reduction might be referred to a direct influence of formaldehyde produced during methanol metabolism following aspartame administration.
GPx plays a major role in the reductive detoxification of peroxides in cells and is involved in conversion of hydrogen peroxide to water in the presence of glutathione as hydrogen donor [39]. The decrease in GPx activity may lead to formation of hydroxyl radical from hydrogen peroxide which may participate in oxidative stress [40]. GR is an important enzyme in cellular antioxidant defense system and plays a critical role in the maintenance of GSH in liver. GR catalyses the conversion of oxidized glutathione (GSSG) to reduced glutathione which plays a vital role in scavenging free radicals. The reduction in the activity of GR may denote a deficit in formation of GSSG back from GSH in the presence of GPx [41]. In the meantime, there was a significant decrease in SOD and CAT activities in liver and renal tissues following oral administration of aspartame. SOD is an enzyme that repairs cells and decreases their damage through conversion of endogenous cytotoxic superoxide radicals to hydrogen peroxide and ordinary molecular oxygen, which have harmful effects on proteins and polyunsaturated fatty acids [42]. CAT is an important enzyme in protecting the cell from oxidative damage by catalyzing the decomposition of hydrogen peroxide to water and oxygen [43]. In the presence of insufficient activity of CAT to decompose hydrogen peroxide, more of it could be converted to toxic hydroxyl radicals that might contribute to oxidative stress because of methanol metabolite from aspartame. Methanol intake has been shown to reduce the activities of antioxidant enzymes SOD, CAT and GPx in the lymphoid organs [14]. Diminished activity of antioxidant enzymes SOD, CAT, GPx and GR is possibly associated with the action of methanol metabolites such as free radicals and formaldehyde. The reduction of these enzymes activities might be owing to their inactivation caused by production of high number of free radicals [44] following aspartame ingestion. Moreover, free radicals produced during the oxidation of methanol can lead to formation of protein peroxides. In addition, formaldehyde can react with the amino acids of solube proteins resulting in hydroxymethyl derivatives and intermolecular bridges in proteins [45]. It has been reported that formaldehyde exposure caused a decrese in the activities of SOD and CAT in the liver tissue [46]. This concur previous study indicated an inhibition in the activity of SOD and there was a dose response relationship between formaldehyde concentration and SOD activity [47]. Another study revealed that the SOD activity in the renal tissue was remarkably inhibited in formaldehyde treated animals [18]. Glutathione-S-transferases represent a group of detoxification enzymes which catalyse the conjugation of reduced glutathione to a wide variety of compounds, and involving in the detoxification of xenobiotics and signaling cascades [48]. The elevation in GST activity observed in the present study could be a response of the tissue to the oxidative stress stimulated by methanol intoxication following aspartame intake, or perhaps due to stimulation of GST synthesis by aspartame. This is in accordance with earlier report indicated that aspartame exposure led to a significant increase in GST activity in the liver tissue [49].

The study also hypothesized that aspartame intake may cause liver injury which was marked by the elevation in the 
activities of ALT, AST, ALP and GGT in blood serum. The stimulated activities of these enzymes observed in the present investigation probably caused by methanol, a metabolite of aspartame, which is previously recorded to cause alteration in oxidant/antioxidant balance and surface charge density followed by leakage of AST and ALT [14]. ALP is a membrane associated enzyme which plays a role in the process of dephosphorylation. Increment in its activities can be used as an indicator of liver injury [50]. GGT is a microsomal enzyme present in liver tissue and plays an important role in metabolizing of extracellular GSH allowing for precursor amino acids to be assimilated and reutilized for synthesis of intracellular GSH. An elevation in serum GGT can be considered as a defense mechanism reflecting the induction of cellular GGT in the case of oxidative stress [51].

\section{CONCLUSION}

The data provided in this study clearly point out that aspartame consumption at a dose of $50 \mathrm{mg} / \mathrm{kg}$ of body weight induces oxidative stress in hepatic and renal tissues by generation of free radicals. Methanol and formaldehyde, the byproducts of aspartame metabolism, might be the causative factors behind the alterations observed. As the days of consumption increased induces more oxidative stress and disturbing the homeostasis status in the whole body. According to these observations, it is possible to say that aspartame consumption is not safe and it is necessary to be careful when using it as a sweetener in beverages and food. Therefore, this investigation emphasises the need to caution people who are using aspartame routinely.

\section{REFERENCES}

1. Magnuson BA, Burdock GA, Doull J, Kroes RM, Marsh GM, Pariza MW, Spencer PS, Waddell WJ, Walker R, Williams GM. Aspartame: a safety elevation based on current use levels, regulations, and toxicological and epidemiological studies. Crit Rev Toxicol. 2007; 37:629-727.

2. Rencuzogullari E, Tuylu BA, Topaktas M, Ila HB, Kayraldiz A, Arslan M, Diler SB. Genotoxicity of aspartame. Drug Chem Toxicol. 2004; 27:257-268.

3. Oppermann JA. Aspartame metabolism in animals. In: Stegink LD, Filer LJ (ed). Aspartame, physiology and biochemistry. Marcel Dekker Inc, New York; 1984, pp 141-159.

4. Stegink LD. Aspartame metabolism in humans: acute dosing studies. In: Stegink L, Filer L (ed) Aspartame: Physiology and biochemistry. Marcel Dekker, New York; 1984, pp 509-553.

5. Trocho C, Pardo R, Rafecas I, Virgili J, Remesar X, FernandezLopez JA, Alemany M. Formaldehyde derived from dietary aspartame binds to tissue components in vivo. Life Sci. 1998; 63:337-349.

6. Woodrow C. Monte and methanol. J Appl Nutr. 1984; 36:1-15.

7. Maher TJ and Wurtman RJ. Possible neurologic effects of aspartame, a widely used food additive. Environ Health Perspect. 1987; 75:5357.

8. Dailey JW, Lasley SM, Burger RL, Bettendorf AF, Mishra PK and Jobe PC. Amino acids, monoamines and audiogenic seizures in genetically epilepsy-prone rats: effects of aspartame. Epilepsy Res. $1991 ; 8: 122-133$.

9. Diomede L, Romano M, Guiso G, Caccia S, Nava S, Salmona M. Interspecies and interstrain studies on the increased susceptibility to metrazol-induced convulsions in animals given aspartame. Food Chem Toxicol. 1991; 29:101-106.
10. Humphries P, Pretorius E, Naude H. Direct and indirect cellular effects of aspartame on the brain. Eur J Clin Nutr. 2008; 62:451-462.

11. Kruse JA. Methanol poisoning. Intensive Care Med. 1992; 18:391397.

12. Davoli E. Serum methanol concentrations in rats and in men after a single dose of aspartame. Food Chem Toxicol. 1986; 24:187-189.

13. Poli G. Liver damage due to free radicals. Br Med Bull. 1993; 49:604-609.

14. Parthasarathy JN, Ramasundaram SK, Sundaramahalingam M, Pathinasamy SD. Methanol induced oxidative stress in rat lymphoid organs. J Occup Health. 2006; 48:20-27.

15. Castro GD, Costantini MH, Delgado de layno AM, Castro A. Rat liver microsomal and nuclear activation of methanol to hydroxyl methyl free radicals. Toxicol Lett. 2002; 129:227-236.

16. Ishak KG, Zimmerman HJ, Ray MB. Alcoholic liver disease: pathologic, pathogenetic and clinical aspects. Alcohol Clin Exp Res. 1991; 15:45-66.

17. Fernandez-Checa JC, Kaplowitz N, Colell A, Garcia-Ruiz C. Oxidative stress and alcoholic liver disease. Alcohol Health Res World. 1997; 21:321-324.

18. Betteridge DJ. What is oxidative stress. Metabolism. 2000; 49:3-4.

19. Lopaczyski W, Zeisel SH. Antioxidants, programmed cell death, and cancer. Nutr Res. 2001; 21:295-307.

20. Karim A, Burns T. Metabolism and pharmacokinetics of radio labeled aspartame in normal subjects. In: Tschanz C, Butchko HH, Stargel WW, Kotsonis FN(ed) The clinical evaluation of a food additive. Assessment of aspartame. Boca Raton, New York, London, Tokyo: CRC; 1996, pp 57-66.

21. Stegink LD, Filer LJ. Effects of aspartame ingestion on plasma aspartate, phenylalanine and methanol concentrations in normal adults. In: Tschanz C, Butchko HH, Stargel WW, Kotsonis FN (ed) The clinical evaluation of a food additive. Assessment of aspartame. Boca Raton, New York, London, Tokyo: CRC Press; 1996, pp 67-86.

22. Trefz FK, Bickel H. Tolerance in PKU heterozygotes. In: Tschanz C, Butchko HH, Starge, WW, Kotsonis FN (ed) The clinical evaluation of a food additive. Assessment of aspartame; 1996, pp. 149-160.

23. Stegink LD. The aspartame story: a model for the clinical testing of a food additive. Am J Clin Nutr. 1987; 46:204-215.

24. Cheese-man KH. Mechanisms and effects of lipid peroxidation. Mol Aspects Med. 1993; 14:191-197.

25. Mylonas $\mathrm{C}$ and Kouretas D. Lipid peroxidation and tissue damage. In vivo. 1999; 13:295-309.

26. Bergendi L, Benes L, Durackova Z, Ferencik. Chemistry, Physiology and Pathology of free radicals. Life Sci. 1999; 65:1865-1874.

27. Zeyuan D, Bingyin T, Xiaolin L, Jinming H, Yifeng C. Effect of green tea and black tea on the blood glucose, the blood triglycerides and antioxidation in aged rats. J Agric Food Chem. 1998; 46:38753878.

28. Zararsiz I, Sarsilmaz M, Tas U, Kus I, Meydan S, Ozan E. Protective effect of melatonin against formaldehyde- induced kidney damage in rats. Toxicol Ind Health. 2007; 23:573-579.

29. Winterbourn CC. Concerted antioxidant activity of glutathione and superoxide dismutase. In: Packer L, Fuchs J (ed) Biothiols in health and disease. Marcel Dekker Inc, New York; 1995, pp 117-34.

30. Abuja PM, Albertini R. Methods for monitoring oxidative stress, lipid peroxidation and oxidation resistance of lipoproteins. Clin Chim Acta. 2001; 306:1-17.

31. Singh P, Mann KA, Mangat HK, Kaur G. Prolonged glutamate excitotoxicity: Effects of mitochondrial antioxidants and antioxidan enzymes. Mol Cell Biochem. 2003; 243:139-145.

32. Hashimoto K, Takasaki W, Yamoto T, Manabe SI, Tsuda S. Effect of glutathione (GSH) depletion on DNA damage and blood chemistry in aged and young rats. J Toxicol Sci. 2008; 33:421-429.

33. Jones DJ, Eklow L, Thor H, Orrenius S. Metabolism of hydrogen peroxide in isolated hepatocytes: relative contribution of catalase and glutathione peroxidase in decomposition of endogenous generated H2O2. Arch Biochem Biophys. 1981; 210:505-516.

34. Meister A, Anderson S. Glutathione . Ann Rev Biochem. 1983; 52: 711-760. 
35. Oyama Y, Sakai H, Arata T, Okano Y, Akaike N, Sakai K, Noda K. Cytotoxic effects of methanol, formaldehyde and formate on dissociated rat thymocytes: a possibility of aspartame toxicity. Cell Biol Toxicol. 2002; 18:43-50.

36. Pankow D, Jagielki S. Effect of methanol on modifications of hepatic glutathione concentration on the metabolism of dichloromethane to carbon monoxide in rats. Hum Exp Toxicol. 1993; 12:227-231.

37. Sogut, S, Songur A, Ozen OA, Ozyurt H, Sarsilmaz M. Does the sub acute (4 week) exposure to formaldehyde inhalation lead to oxidant/antioxidant imbalance in rat liver. Eur J Gen Med. 2004 1:26-32.

38. Skrzydlewska E. Toxicological and metabolic consequences of methanol poisoning. Toxicol Mechan Methods. 2003; 13:277-293.

39. Prabhakar R, Vreven T, Morokuma K, Musaev DG. Elucidation of the mechanism of selenoprotein glutathione peroxidase (GPx) catalyzed hydrogen peroxide reduction by two glutathione molecules: a density functional study. Biochemistry. 2005; 44:11864-11871.

40. Reiter RJ. Melatonin: lowering the high price of free radicals. News Physiol Sci. 2000; 15:246-250.

41. Morena I, Pichardo S, Jos A, Gomez-Amores L, Mate A, Vasquez $\mathrm{CM}$, Camean AM. Antioxidant enzyme activities and lipid peroxidation in liver and kidney of rats exposed to Microcystin LR administered intraperitoneally. Toxicon. 2005; 45:395-402.

42. Fridovich I. Superoxide dismutase. Ann Rev Biochem. 1975; 44:147159.

43. Kono Y, Fridorich I. Superoxide radical inhibits catalase. J Biol Chem. 1982; 257:5751-5754.

44. Pigeolet E, Corbisler P, Houbion A. Glutathione peroxidase, superoxide dismutase, and catalase inactivation by peroxides and oxygen derived free radicals. Mech Ageing Dev. 1990; 51:283-97.

45. Skrzydlewska E, Elas M, Farbiszewski R, Roszkowska A. Effect of methanol intoxication on free-radical induced protein oxidation. $\mathrm{J}$ Appl Toxicol. 2000; 20:239-243.
46. Gulec M, Gurel A, Armutcu F. Vitamin E protects against oxidative damage caused by a formaldehyde in the liver and plasma of rats. Mol Cell Biochem. 2006; 290:61-67.

47. Chang JR, Xu DQ. Effects of formaldehyde on the activity of superoxide dismutase and glutathione peroxidase and the concentration of malondialdehyde. Wei Sheng Yan Jiu Sept. 2006; 35:653- 655 .

48. Tuna G, Erkmen GK, Dalmizrak O, Dogan A, Ogus IH, Ozer N. Inhibition characteristics of hypericin on rat small intestine glutathione- S- transferase. Chem Biol Interact. 2010; 188:59-65.

49. Mourad IM. Effect of aspartame on some oxidative stress parameters in liver and kidney of rats. Afr J Pharm Pharmacol. 2011; 5:678-682.

50. Giannini EG, Testa R, Savarino V. Liver enzyme alteration: a guide for clinicians. CMAJ. 2005; 172:367-379.

51. Lee DH, Blomhoff R, Jacobs DR. Serum gamma glutamyl transferase a marker of oxidative stress. Free Radical Res. 2004; $38: 535-539$

\section{How to cite this article:}

Saeed A. Alwaleedi. Alterations in antioxidant defense system in hepatic and renal tissues of rats following aspartame intake. J App Biol Biotech. 2016; 4 (02): 046-052. DOI: 10.7324/JABB.2016.40207 